\title{
The genotype of a new linked DNA marker, MP6d-9, is related to the clinical course of cystic fibrosis
}

Paolo Gasparini, Giuseppe Novelli, Xavier Estivill, Dario Olivieri, Anna Savoia, Anna Ruzzo, Virginia Nunes, Graziella Borgo, Mariano Antonelli, Robert Williamson, Pier Franco Pignatti, Bruno Dallapiccola

\begin{abstract}
The clinical symptoms of a cohort of cystic fibrosis patients were related to their genotypes using RFLPs shown with $M s p I$ and the closely linked DNA marker MP6d-9. In the majority of CF chromosomes, the restriction site for $M s p I$ was present, and the genotype $2 / 2$ was found most often in patients who were severely affected by the disease. The genotype $1 / 2$ was significantly overrepresented in patients with very mild clinical manifestations, including pancreatic sufficiency, absence of meconium ileus, and absence of Pseudomonas colonisation. When pancreatic dysfunction was present, the $1 / 2$ genotype was associated with a mild form, while the $2 / 2$ genotype was found in
\end{abstract}

Istituto di Scienze Biologiche, Università di Verona, Strada Le Grazie, 37134 Verona, Italy.

P Gasparini, A Savoia, P F Pignatti

Cattedra di Genetica, Dipartimento di Sanità Pubblica e Biologia Cellulare, II $^{\circ}$ Università di Roma ed Università di Urbino, Rome, Italy.

G Novelli, A Ruzzo, B Dallapiccola

Centro di Calcolo, Università di Verona, Verona, Italy. D Olivieri

Centro Regionale Veneto Fibrosi Cistica, Verona, Italy. G Borgo

Clinica Pediatrica, Università 'La Sapienza', Rome, Italy. M Antonelli

Unidad de Biologia Molecular, Hospital de la Santa Creu I Sant Pau, Barcelona, Spain.

$\mathrm{X}$ Estivill, V Nunes

Department of Biochemistry, St Mary's Hospital Medical School, London W2 1PG.

R Williamson

Correspondence to Dr Pignatti

Received for publication 8 July 1989.

Revised version accepted for publication 14 August 1989. patients with severe insufficiency. None of our patients had the $1 / 1$ genotype. These results indicate that the newly isolated MP6d-9 marker correlates with some important symptoms of cystic fibrosis.

Cystic fibrosis (CF) is an autosomal recessive disease with a prevalence of about 1 in 2000 live births and a carrier frequency of approximately 1 in 23 in Caucasian populations. $^{1}$

Linkage analysis has localised the CF mutation close to a protein variant, ${ }^{2}$ and then assigned it to the long arm of chromosome 7 using DNA markers. ${ }^{3-5}$ Several DNA probes tightly linked to the CF gene are currently in use for carrier detection and prenatal diagnosis in families with at least one affected child. $^{6-9}$

The newly isolated marker, pMP6d-9 (D7S399), maps between the DNA sequences recognised by pKM19 (D7S23) and pJ3.11 (D7S8). ${ }^{10}$ pMP6d-9 is the closest, to date, to $C F$ and is the one that shows the highest degree of non-random allelic association (linkage disequilibrium) in the Italian population. ${ }^{11}$ We report here a study on the correlation between the allelic systems determined by pMP6d-9, pXV2C, pKM.19, and pJ3.11 and the clinical manifestations of cystic fibrosis, including meconium ileus, pancreatic function, Pseudomonas colonisation, lung involvement, congestive cardiomyopathy, diabetes, biliary cirrhosis, and nasal polyposis.

\section{Subjects and methods} PATIENTS

Data were collected from 86 unrelated Italian patients attending the CF centres of Verona and Rome. Blood samples were obtained in each family from parents and one affected child for DNA genotyping. CF diagnosis was confirmed with at least two positive sweat tests, performed according the method of Gibson and Cooke. ${ }^{12}$ 
DNA GENOTYPING AND STATISTICAL INALYSIS

Genomic DNA was prepared from whole blood by standard methods. Restriction endonuclease digestion, transfer of DNA fragments to nylon or nitrocellulose membranes (Hybond-N and Hybond-CE, Amersham International), hybridisation, and autoradiography were carried out as previously described. ${ }^{13}$ The pMP6d-9/MspI, ${ }^{10}$ pKM19/Pst I, ${ }^{8}$ pXV2C/TaqI, ${ }^{7}$ and $\mathrm{pJ} 3.11 / \mathrm{MspI}^{4}$ RFLPs were determined for each family. Different tests (normal test, $\chi^{2}$ test, and Fisher's exact test) were used to estimate the difference of proportion. The linkage disequilibrium analysis has been reported elsewhere. ${ }^{11}$

\section{CLINICAL ASSESSMENT}

Clinical data were obtained from patients basically according to a protocol previously reported, ${ }^{13 a}$ in which a form, designed by several of the cooperating clinical groups, was used to collect information for each patient. Ileal obstruction at birth requiring medical or surgical therapy was defined as meconium ileus. Pancreatic insufficiency was defined on the basis of clinical course, steatorrhoea (stool fat g/day), or fat balance (coefficient of fat absorption), or steatocrit, or all of these. ${ }^{14}$ The pulmonary function was established by analysing several successive chest $x$ rays according to Chrispin and Norman. ${ }^{15}$ The slope and a $Y$ intercept of the regression line of the radiological score were used for the analysis, dividing the patients into three classes (mild, moderate, and severe lung involvement). Pseudomonas colonisation (established through serial sputum cultures) was

Table 1 MP6d-9 genotypes of CF patients.

\begin{tabular}{lccccc}
\hline & \multicolumn{2}{c}{ Patients } & & \multicolumn{2}{c}{ Parents } \\
\cline { 2 - 3 } \cline { 5 - 6 } Genotype & No & $\%$ & & No & $\%$ \\
\hline 1,1 & $0^{*}$ & 0 & & $10^{*}$ & 7 \\
1,2 & 32 & 37 & & 103 & 70 \\
2,2 & 54 & 63 & & 34 & 23 \\
Total & 86 & 100 & & 147 & 100 \\
\hline
\end{tabular}

Some parental samples were not available for analysis. ${ }^{*}=\mathrm{p}<0.05$. defined according to age at first appearance. The presence of other complications, such as diabetes, biliary cirrhosis, or nasal polyposis, was also registered. The mean age of our patient sample was 9 years 7 months.

\section{Results}

Table 1 shows the MP6d-9 genotypes of a sample of our CF patients: $63 \%$ had the $2 / 2$ genotype and $37 \%$ the $1 / 2$ genotype. The $1 / 1$ genotype was not seen in this group of 86 patients, but it was present in $7 \%$ of their carrier parents. This difference is statistically significant. Linkage disequilibrium analysis for this population has been reported elsewhere. ${ }^{11}$

Table 2 records the distribution of the clinical manifestations in our patients. Lung involvement was present in all patients and in the majority pancreatic insufficiency was present and meconium ileus was absent. No significant association of genotypes with the severity of pulmonary involvement, or with meconium ileus, Pseudomonas colonisation, nasal polyposis, or other complications was observed.

The analysis of the relation between MP6d-9 genotypes and pancreatic dysfunction is shown in table 3. This table shows that there is a significant difference in the distribution of the MP6d-9 genotypes, with an overrepresentation of the 1/2 genotype in pancreatic sufficient, and of the $2 / 2$ genotype in pancreatic insufficient patients. The mean ages of the patients included in the two groups were 8.7 years (insufficiency) and 14.6 years (sufficiency). All cases with pancreatic sufficiency had therefore reached an age at which the total or partial conservation of function allowed this group to be differentiated from the other. A similar analysis was performed with the pXV2C/TaqI, pKM19/PstI, and pJ3.11/MspI RFLPs. A significant association of the KM19 genotype $2 / 2$ with pancreatic insufficiency was found, but no significant relation with the other two polymorphisms. It appears that haplotype 2,2 for J3.11 and haplotype 1,1 for $\mathrm{pXV} 2 \mathrm{C}$ are also related to pancreatic dysfunction. It should be noted that the number of observations for the $\mathrm{J} 3.11$ polymorphism was the lowest.

Table 2 Distribution of the clinical manifestations of CF patients.

\begin{tabular}{|c|c|c|c|c|c|c|}
\hline \multirow[b]{2}{*}{ Clinical manifestation } & \multicolumn{2}{|c|}{ Present } & \multicolumn{2}{|c|}{ Absent } & \multicolumn{2}{|c|}{ Uncertain } \\
\hline & No & $\%$ & No & $\%$ & No & $\%$ \\
\hline $\begin{array}{l}\text { Lung involvement } \\
\text { Meconium ileus } \\
\text { Pancreatic insufficiency } \\
\text { Pseudomonas colonisation } \\
\text { Nasal polyposis } \\
\text { Other complications } \\
\text { (diabetes or cirrhosis) }\end{array}$ & $\begin{array}{r}54 \\
16 \\
69 \\
36 \\
7 \\
3\end{array}$ & $\begin{array}{r}100 \\
19 \\
80 \\
42 \\
8 \\
3\end{array}$ & $\begin{array}{r}0 \\
63 \\
11 \\
44 \\
74 \\
78\end{array}$ & $\begin{array}{r}0 \\
73 \\
13 \\
51 \\
86 \\
91\end{array}$ & $\begin{array}{l}0 \\
7 \\
6 \\
6 \\
5 \\
5\end{array}$ & $\begin{array}{l}0 \\
8 \\
7 \\
7 \\
6 \\
6\end{array}$ \\
\hline
\end{tabular}

Percentage is computed by row. 
Table 3 Distribution of genotypes of CF patients by pancreatic involvement.

\begin{tabular}{|c|c|c|c|c|c|}
\hline \multirow[b]{2}{*}{ RFLP } & \multirow[b]{2}{*}{ Genotype } & \multicolumn{2}{|c|}{ Sufficiency } & \multicolumn{2}{|c|}{ Insufficiency } \\
\hline & & No & $\%$ & No & $\%$ \\
\hline MP6d-9/MspI & $\begin{array}{l}1,2 \\
2,2\end{array} \mid *$ & $\begin{array}{l}7 \\
4\end{array}$ & $\begin{array}{l}26 \\
7.5\end{array}$ & $\begin{array}{l}20 \\
49\end{array}$ & $\begin{array}{l}74 \\
92.5\end{array}$ \\
\hline KM19/PstI & $\begin{array}{l}1,1 \\
1,2 \\
2,2\end{array} \mid$ * & $\begin{array}{l}2 \\
7 \\
3\end{array}$ & $\begin{array}{l}1 \\
27 \\
6\end{array}$ & $\begin{array}{r}9 \\
19 \\
49\end{array}$ & $\begin{array}{c}1 \\
73 \\
94\end{array}$ \\
\hline $\mathrm{XV} 2 \mathrm{C} / \mathrm{Taq} \mathrm{I}$ & $\begin{array}{l}1,1 \\
1,2 \\
2,2\end{array}$ & $\begin{array}{l}4 \\
8 \\
1\end{array}$ & $\begin{array}{r}9 \\
23 \\
1\end{array}$ & $\begin{array}{r}42 \\
27 \\
4\end{array}$ & $\begin{array}{r}91 \\
77 \\
/\end{array}$ \\
\hline $\mathrm{J} 3.11 / M s p \mathrm{I}$ & $\begin{array}{l}1,1 \\
1,2 \\
2,2\end{array}$ & $\begin{array}{l}0 \\
5 \\
0\end{array}$ & $\begin{array}{l}1 \\
26\end{array}$ & $\begin{array}{r}5 \\
14 \\
20\end{array}$ & $\begin{array}{r}1 \\
74 \\
100\end{array}$ \\
\hline
\end{tabular}

*p<0.03. I=total number of observations too low to compute percentage.

Table 4 Distribution of MP6d-9 genotypes of CF patients by severe or minimal pancreatic insufficiency.

\begin{tabular}{lll}
\hline Genotype & & \\
& Steatocrit & \\
1,2 & Light $(2-6 \%)$ & Severe $(>6 \%)$ \\
2,2 & $3^{*}$ & 0 \\
& 0 & $11^{*}$ \\
& Fat absorption & coefficient \\
1,2 & Light $(>70 \%)$ & Severe $(<70 \%)$ \\
2,2 & 5 & 5 \\
& 6 & 18 \\
1,2 & Steatorrhoea & \\
2,2 & Light $(<9$ g/day $)$ & Severe $(>10$ g/day $)$ \\
\hline
\end{tabular}

${ }^{*}$ Fisher's exact test $\mathrm{p}=0 \cdot 00275$.

A further, more detailed analysis of the relation between the MP6d-9 genotype and the severity of pancreatic insufficiency is shown in table 4 . When pancreatic insufficient patients were divided into two groups, according to the severity of the pancreatic dysfunction, it was found that the MP6d-9 $1 / 2$ genotype was overrepresented in the mild form, defined by $<9 \mathrm{~g}$ /day steatorrhoea (without pancreatic enzyme supplementation), or by a steatocrit of $<6 \%$, or by a coefficient of fat absorption of $>70 \%$. This relation is highly significant for steatocrit, where the sample size is lowest, and almost significant $(p=0.087)$ for steatorrhoea. Steatocrit has low specificity and high sensitivity and might depend, as well as steatorrhoea, on different dietary fat intake. Fat absorption, however, is independent of age, normalised for body weight, and calculated relative to known fat intake.

Table 5 shows the relation between MP6d-9 genotypes and a division of CF into severe and mild clinical forms. Pancreatic insufficiency, meconium ileus, and Peudomonas colonisation were used as the major criteria to identify the two classes, the first including patients without any of the above manifestations, and the second including patients with one or more of them. The ages of the patients included in
Table 5 Distribution of CF patient genotypes by severe or mild clinical course.

\begin{tabular}{|c|c|c|c|c|c|}
\hline \multirow[b]{2}{*}{ RFLP } & \multirow[b]{2}{*}{ Genotype } & \multicolumn{2}{|c|}{ Absence } & \multicolumn{2}{|c|}{ Presence } \\
\hline & & No & $\%$ & No & $\%$ \\
\hline MP6d-9/MspI & $1,2 \mid *$ & 9 & 28 & 23 & $\begin{array}{l}72 \\
94\end{array}$ \\
\hline KM19/PstI & $\begin{array}{l}1,1 \\
1,2\end{array}$ & $\begin{array}{l}1 \\
7\end{array}$ & ' & $\begin{array}{l}10 \\
22\end{array}$ & $\begin{array}{l}1 \\
76\end{array}$ \\
\hline $\mathrm{XV} 2 \mathrm{C} / \mathrm{Taq} \mathrm{I}$ & $\begin{array}{l}2,2 \\
1,1 \\
1,2 \\
2,2\end{array}$ & $\begin{array}{l}4 \\
3 \\
8 \\
1\end{array}$ & $\begin{array}{r}7 \\
6 \\
20 \\
1\end{array}$ & $\begin{array}{r}51 \\
44 \\
32 \\
4\end{array}$ & $\begin{array}{l}93 \\
94 \\
80 \\
1\end{array}$ \\
\hline $\mathrm{J} 3.11 / M s p I$ & $\begin{array}{l}1,1 \\
1,2 \\
2,2\end{array}$ & $\begin{array}{l}1 \\
2 \\
0\end{array}$ & $\begin{array}{l}1 \\
11\end{array}$ & $\begin{array}{r}5 \\
17 \\
20\end{array}$ & $\begin{array}{c}1 \\
89 \\
100\end{array}$ \\
\hline
\end{tabular}

Absence $=$ absence of meconium ileus, $P$ seudomonas colonisation, and pancreatic insufficiency. Presence $=$ presence of one or more of the above symptoms. ${ }^{*} \mathrm{p}<0.01$. I = total number of observations too low to compute percentage.

the two groups were $9 \cdot 3$ years (with) and $11 \cdot 8$ years (without). The lack of Pseudomonas colonisation, therefore, was not related to the age of the patients, as it would be a progressive change over time. A highly significant difference of distribution of MP6d-9 genotypes was found: genotype $1 / 2$ is overrepresented in the first class, corresponding to minimal disease. This genotype was not seen in CF patients manifesting all three clinical features. The same analysis did not indicate significant correlations with genotype for any of the other RFLPs investigated. The MP6d-9 RFLP, therefore, showed a better ability to discriminate between mild and severe CF than other linked RFLPs. In addition, complications (diabetes and biliary cirrhosis) were observed only in patients with the MP6d-9 genotype 2/2.

\section{Discussion}

pMP6d-9 is the DNA marker most tightly linked to CF available at present. ${ }^{10}$ Therefore, this marker currently offers the best possibility of relating individual genotype to clinical presentation and course of cystic fibrosis. In Italian families, the correlation coefficient for linkage disequilibrium between MP6d-9 and KM19 is 0.73 and between MP6d-9 and $\mathrm{XV} 2 \mathrm{C}$ is 0.43 on CF chromosomes. ${ }^{11}$ We have found that MP6d-9 allele 1 is associated with milder disease. Three of the most common features of cystic fibrosis were used as indicators of the degree of severity: pancreatic insufficiency, Pseudomonas colonisation, and meconium ileus. This last symptom is the earliest clinical manifestation of cystic fibrosis, and may be related to the decrease in pancreatic enzymes, to the decrease in water, to the increase in protein, or to the altered secretion of small intestinal mucus. The determination of the genotype of the patient or fetus will therefore indicate some of the most important symptoms of the disease. Genotype 2/2 correlates with 
a more severe clinical spectrum and genotype $1 / 2$ with a milder clinical picture. In an early attempt to correlate different clinical presentations of CF with genotype, Mornet et $a l^{16}$ reported that the CF chromosomes have different J3.11 haplotypes in cases with and without meconium ileus. It was suggested that multiallelism was associated with the two forms of the disease. $\mathrm{J} 3.11$ is located at approximately 0.028 recombination units from $\mathrm{CF} .{ }^{17} \mathrm{We}$ found little, if any, association between MP6d-9 and J3.11. No relation between the occurrence of meconium ileus and alleles of the two closer markers, pXV2C and pKM19, was found in this study, nor in another recent report, which did not confirm the J3.11/ileus association. ${ }^{18}$

Unfortunately, no association of genotype with pulmonary function was found. A collaborative study in Italy ${ }^{13 a}$ has recently shown that specific pKM19 alleles associate preferentially in patients with and without pancreatic insufficiency. A similar conclusion has been reached independently for the W3D1.4/ HindIII RFLP. ${ }^{19}$ W3D1.4 recognises the same region as XV2C. Its linkage disequilibrium with $\mathrm{CF}$ in our sample is 0.17 (unpublished data), compared with 0.30 for XV2C. ${ }^{11}$ Our sample showed the same preference of association of W3Dl.4 with pancreatic disease as reported by the above group. The results reported here, relative to the new DNA marker MP6d-9, more closely linked to the CF mutation, confirm and extend these data, presenting a further and stronger relation between the MP6d-9 genotypes and severe and mild pancreatic insufficiency, as well as three different clinical variables, in each case haplotype $1 / 2$ being preferentially associated with the mild form. Three families with affected sibs were used in this study. Variation in severity (but concordance in pancreatic function) was observed in all of them.

In previous studies of $\mathrm{CF}$ families from southern Europe we have shown the presence of at least one further 'CF haplotype' in addition to the one commonly found in over $85 \%$ of northern European chromosomes, ${ }^{811} 13$ indicating the occurrence of a second CF mutation. The observations reported here support this conclusion and could tentatively be explained by the presence of two different mutations in a single 'cystic fibrosis gene': a 'mild' one associated with the MP6d-9 allele 1 and a 'severe' one associated with the MP6d-9 allele 2. These data would be most compatible with mutations in a coding sequence that result in two different amino acid substitutions in a polypeptide chain with different phenotypic effects, as is found in the haemoglobinopathies. Patients with the $2 / 2$ genotype would be affected more seriously than those with the $1 / 2$ genotype, as we observed. We hypothesise that a subject with the 1/1 genotype would not present with classical $\mathrm{CF}$ at all, but perhaps with a less severe disease.
We wish to thank Professor G Mastella for encouragement and helpful collaboration; $M \mathrm{~T}$ Miscio, $\mathrm{R}$ Galavotti, $P$ Lorenzi, and $M$ Arena for expert technical assistance; Drs J Buchanan, M Buchwald, and L C Tsui for generously making data available in advance of publication; the Cystic Fibrosis Centre of Verona, Italy; the Italian Ministry of Public Education; the Golden Products (Italy); the Spanish Ministry of Social Security (89/0563); the Spanish Ministry of Education and Science (PB87-0074); and the Cystic Fibrosis Research Trust (UK) for support. PG and AS were recipients of fellowships from the Cystic Fibrosis Centre of Verona, AR from the Italian Society of Prenatal Medicine.

1 McKusick VA. Mendelian inheritance in man. 8th ed. Baltimore, London: Johns Hopkins University Press, 1988.

2 Eiberg H, Mohr J, Schmiegelow K, Nielsen LS, Williamson $R$ Linkage relationships of paraoxonase (PON) with other markers: indication of PON-cystic fibrosis synteny. Clin Genet 1985;28:265-71.

3 Knowlton RG, Cohen-Haguenauer O, Van Cong N, et al. A polymorphic DNA marker linked to cystic fibrosis is located on chromosome 7. Nature 1985;318:380-2.

4 Wainwright B, Scambler P, Schmidtke J, et al. Localization of cystic fibrosis locus to human chromosome 7cen-q22. Nature 1985;318:384-5.

5 White R, Woodward S, Leppert M, et al. A closely linked genetic marker for cystic fibrosis. Nature 1985;318:382-4.

6 Farrall M, Rodeck $\mathrm{CH}$, Stainer $\mathrm{P}$, et al. First trimester prenatal diagnosis of cystic fibrosis with linked DNA probes. Lancet 1986;i: 1402-5.

7 Estivill X, Farrall M, Scambler P, et al. A candidate gene for the cystic fibrosis locus isolated by selection for methylation-free islands. Nature 1987;326:840-5.

8 Estivill X, Scambler P, Wainwright B, et al. Patterns of polymorphisms and linkage disequilibrium for cystic fibrosis. Genomics 1987;1:257-63.

9 Gasparini P, Novelli G, Savoia A, Dallapiccola B, Pignatti PF. First trimester prenatal diagnosis of cystic fibrosis using the polymerase chain reaction: report of 8 cases. Prenat Diagn 1989;9:349-55.

10 Estivill X, McLean C, Nunes V, et al. Isolation of a new DNA marker in linkage disequilibrium with cystic fibrosis, situated between J3.11 (D7S8) and IRP. Am F Hum Genet 1989;44:704 10.

11 Estivill X, Gasparini P, Novelli G, et al. Linkage disequilibrium for DNA haplotypes near the cystic fibrosis locus with two South European populations. Hum Genet 1989;83:175-8.

12 Gibson LE, Cooke RE. A test for concentration of electrolytes in sweat in cystic fibrosis of pancreas utilizing pilocarpine by iontophoresis. Pediatrics 1959;23:545-51.

13 Estivill $X$, Farrall $M$, Williamson $R$, et al. Linkage disequilibrium between cystic fibrosis and linked polymorphic DNA markers in Italian families: a collaborative study. Am $\mathcal{f} \mathrm{Hum}$ Genet 1988;43:23-8.

$13^{\mathrm{a}}$ Ferrari M, Antonelli M, Bellini F, et al. Genetic differences in cystic fibrosis patients with and without pancreatic insufficiency - an Italian collaborative study. Hum Genet (in press).

14 Phuapradit P, Narang A, Mendonca P, Harris DA, Baum JA. The steatocrit: a simple method for estimating stool fat content in newborn infants. Arch Dis Child 1981;56:725-7.

15 Chrispin AR, Norman AP. The systematic evaluation of the chest radiograph in CF. Pediatr Radiol 1974;2:101-10.

16 Mornet E, Simon-Bouy B, Serre JL, et al. Genetic differences between cystic fibrosis with and without meconium ileus. Lancet 1988;i:376-8.

17 Lathrop GM, Farrall M, O'Connell P, et al. Refined linkage map of chromosome 7 in the region of the cystic fibrosis gene. Am $\mathcal{F}$ Hum Genet 1988;42:38-44.

18 Auvinet M, Morel Y, Chambon V, et al. Cystic fibrosis with and without meconium ileus. Lancet 1989;i:161.

19 Kerem B, Buchanan J, Durie P, et al. DNA marker haplotype association with pancreatic sufficiency in cystic fibrosis. $A m \mathcal{F}$ Hum Genet 1989;44:827-34. 